\title{
Primary Adrenal Insufficiency Caused by a Novel Mutation in DAX1 Gene
}

\author{
Olcay Evliyaoğlu1, Ipek Dokurel1, Feride Bucak1, Bahar Özcabı1, Oya Ercan1, Serdar Ceylaner2 \\ ${ }^{1}$ Istanbul University Cerrahpaşa Faculty of Medicine, Department of Pediatric Endocrinology, Istanbul, Turkey \\ 2Intergen, Genetic Diagnosis Research and Application Center, Ankara, Turkey
}

\begin{abstract}
Adrenal hypoplasia congenita $(\mathrm{AHC})$ is a rare disorder. The $\mathrm{X}$-linked form is related to mutations in the DAX1 (NROB1) gene. Here, we report a newborn who had a novel hemizygous frameshift mutation in DAX1 (c.543delA) and presented with primary adrenal failure that was initially misdiagnosed as congenital adrenal hyperplasia. This report highlights the value of genetic testing for definite diagnosis in children with primary adrenal failure due to abnormal adrenal gland development, providing the possibility both for presymptomatic, and in cases with a sibling with this condition, for prenatal diagnosis. Key words: Adrenal, development, insufficiency, DAX1, mutation
\end{abstract}

Conflict of interest: None declared Received: 13.12 .2012

\section{Introduction}

Primary adrenal insufficiency can be caused by a deficiency in steroid biosynthesis or an abnormal adrenal gland development. Adrenal hypoplasia congenita $(\mathrm{AHC})$ is an inherited disorder of adrenal development resulting in primary adrenal insufficiency (1). It has an estimated frequency of 1:12 500 live births (2) and can be inherited as an autosomal recessive or an X-linked disease (3). $X$-linked $\mathrm{AHC}$ is caused by deletions or mutations in DAX1 gene (dosage-sensitive sex reversal, $\mathrm{AHC}$ critical region on the $\mathrm{X}$ chromosome, gene 1; NROB1) situated in Xp21 (4). The DAX1 gene consists of two exons of 1168 and $245 \mathrm{bp}$, respectively, and encodes a 470 amino acid protein which belongs to the nuclear hormone receptor superfamily (5). DAX1 is expressed in the adrenal cortex, in the pituitary, in the hypothalamic ventral nucleus, in Sertoli and Leydig cells in the testis, and in theca and granulosa cells in the ovary $(3,5,6)$. X-linked $A H C$ has variable clinical presentations $(7,8,9)$. Boys with DAX1 mutations typically present with primary adrenal failure. In these patients, the adrenal gland fails to develop fully. Histologically, the adrenal cortex permanent zone is absent, and there are residual cytomegalic cells (10). Urgent mineralocorticoid and glucocorticoid replacement is mandatory (11). Most boys fail to enter puberty and must be given testosterone replacement therapy in adulthood.

Here, we report a male newborn with $\mathrm{AHC}$ who presented with adrenal insufficiency due to a novel mutation in the DAX1 gene.

\section{Case Roport}

A 33-day-old male infant who presented with vomiting and failure to thrive was admitted to the intensive care unit (ICU). His physical examination revealed severe dehydration with normal anthropometric measurements [(length: $52 \mathrm{~cm}$ (3-10\%), weight: $3150 \mathrm{~g}(10 \%)$, head circumference: $37 \mathrm{~cm}(25-50 \%)]$, normal male genital development, and hyperpigmentation of the scrotum and

\footnotetext{
Address for Correspondence

Olcay Evliyaoğlu MD, Istanbul University Cerrahpaşa Faculty of Medicine, Department of Pediatric Endocrinology, Istanbul, Turkey

Phone: +90 4143000 E-mail: olcayevliyaoglu@hotmail.com

This study was presented at $51^{\text {th }}$ European Society of Pediatric Endocrinology (ESPE) Annual Meeting, Leipzig, Germany

@ Journal of Clinical Research in Pediatric Endocrinology, Published by Galenos Publishing.
} 
nipples. Prenatal and birth history (term, birth weight: $3000 \mathrm{~g}$ ) were unremarkable. Parents were fourth-degree relatives. Biochemical measurements showed hyponatremia (Na: 123 $\mathrm{mmol} / \mathrm{L})$, hypochloremia (Cl: $79 \mathrm{mmol} / \mathrm{L})$, hyperkalemia (K: 8.9 $\mathrm{mmol} / \mathrm{L})$, an elevated BUN level: [13.92 $\mathrm{mmol} / \mathrm{L}(39 \mathrm{mg} / \mathrm{dL})]$, and a normal creatinine level: [35.36 $\mu \mathrm{mol} / \mathrm{L}(0.4 \mathrm{mg} / \mathrm{dL})]$. Hormonal evaluation revealed high adrenocorticotropic hormone $(\mathrm{ACTH})$ $275 \mathrm{pmol} / \mathrm{L}$ (>1250 pg/mL) (normal: 0-10.12 pmol/mL) and normal luteinizing hormone (1.24 IU/L) and follicle-stimulating hormone (1.08 IU/L) levels. Baseline and corticotropin-stimulated cortisol, 17(OH) progesterone, 1.4 androstenedione and dehydroepiandrosterone sulfate (DHEA-S) levels are presented in Table 1. Baseline and stimulated levels of cortisol, $17(\mathrm{OH})$ progesterone and androstenedione were low, whereas DHEA-S levels were not as low as was expected according to the agematched references (12). Plasma renin activity; $32.32 \mu \mathrm{g} / \mathrm{L} / \mathrm{hr}$ (normal: 1.9-6.0 $\mu \mathrm{g} / \mathrm{L} / \mathrm{h}$ ) was high, whereas aldosterone level; $0.19 \mathrm{nmol} / \mathrm{L} \quad(7.1 \mathrm{ng} / \mathrm{dL}$ ) (normal:0.96-8.31 nmol/L (35-300 $\mathrm{ng} / \mathrm{dL}$ ) was low. The karyotype of the patient was $46, X Y$. A diagnosis of adrenal insufficiency was made, and treatment with hydrocortisone, fludrocortisone and salt was initiated, to which the patient responded well. Although the patient was initially misdiagnosed as congenital adrenal hyperplasia $(C A H)$ in the ICU, the high ACTH levels with insufficient adrenal steroid production associated with the patient's clinical features suggested that the adrenal insufficiency was related to abnormal adrenal development rather than a steroid biosynthesis defect. Thus, a novel hemizygous frame shift mutation in DAX1 (c.543delA) which would cause loss of function was identified by DNA sequence analysis. DAX1 analyses of both parents were normal.

\section{Discussion}

The incidence of $\mathrm{X}$-linked $\mathrm{AHC}$ is estimated to be between 1:140 000 and 1:200 000 (4). However, there are only two cases reported from Turkey and no reported incidence. The first of these cases was a newborn who presented with adrenal insufficiency on the seventh postnatal day and who had a hemizygous deletion of exons 1 and 2 of DAX1 (13). The second case was a male infant admitted with adrenal failure who showed a novel mutation of Q155X in DAX1 gene and who interestingly developed gonadotropin-dependent precocious puberty at the age of 9 months (14). Our patient had a hemizygous frameshift mutation in DAX1 and, to our knowledge, is the third Turkish patient reported. Frame shift mutations affect protein function severely. These types of mutations frequently cause disease.

Table 1. Baseline and corticotropin-stimulated levels of adrenal androgens in the patient as compared with normal baseline values (12)

\begin{tabular}{|c|c|c|c|c|}
\hline & $\begin{array}{l}\text { Cortisol } \\
(\mu \mathrm{g} / \mathrm{dL})\end{array}$ & $\begin{array}{l}17(\mathrm{OH}) \\
\text { progesterone } \\
(\mathrm{ng} / \mathrm{mL})\end{array}$ & $\begin{array}{l}1.4 \\
\text { androstenedione } \\
(\mathrm{ng} / \mathrm{mL})\end{array}$ & $\begin{array}{l}\text { DHEA-S } \\
(\mu \mathrm{g} / \mathrm{dL})\end{array}$ \\
\hline Baseline & 1.3 & 0.18 & 0.06 & 110.0 \\
\hline $\begin{array}{l}\text { Corticotropin- } \\
\text { stimulated }\end{array}$ & 1.6 & 1.4 & 0.1 & 115.8 \\
\hline $\begin{array}{l}\text { Normal Range } \\
\text { baseline Mean } \\
\text { values }\end{array}$ & $\begin{array}{l}2.01-23.36 \\
7.27 \pm 4.9\end{array}$ & $\begin{array}{l}2.46-8.11 \\
4.78 \pm 134\end{array}$ & $\begin{array}{l}0.18-1.68 \\
0.65 \pm 0.39\end{array}$ & $\begin{array}{l}17.93-174.85 \\
56.48 \pm 32.3\end{array}$ \\
\hline
\end{tabular}

Since the initial identification of DAX1 as the gene responsible for $\mathrm{AHC}$, numerous additional mutations have been discovered including deletions, alterations of splice-sites, missense mutations, nonsense mutations and frame shift mutations $(4,7,1$ $1,15,16,17,18,19,20,21,22,23,24,25,26,27)$.

The clinical picture of $\mathrm{AHC}$ is variable. Approximately 60 $\%$ of the boys with DAX1 mutations have an early onset of primary adrenal failure presenting with salt wasting in the first two months of life that can be misdiagnosed as CAH $(11,27,28)$. In 25 Chinese infant boys with primary adrenal insufficiency, DAX1 gene mutations were found in $40 \%$ (29). Other cases are reported to have a more insidious presentation - symptoms becoming obvious later in childhood and which may be triggered by a stressful incident. A newborn patient who had presented with primary adrenal failure due to missense mutation in DAX1 had an asymptomatic 8-month-old brother with the same mutation, and adrenocorticotropin stimulation test showed impaired adrenal function in the asymptomatic brother (11). This bimodal pattern of presentation may reflect normal age-related changes in mineralocorticoid secretion and sensitivity, in sodium and fluid intake, and in counterregulatory responses (15).

X-linked $\mathrm{AHC}$ is known to be associated with hypogonadotropic hypogonadism $(\mathrm{HHG})$. Prolonged survival of these children into adulthood has shown that $\mathrm{HHG}$ is commonly associated with this disorder $(28,30)$. Although the site of the deficiency within the hypothalamic-pituitary axis has not yet been pinpointed (31), the studies in two kindreds with HHG have shown that the hypothalamus as well as the pituitary and gonads are affected $(26,27)$.

In females, heterozygous mutations in the DAX1 gene have been shown to be associated with delayed menarche, whereas homozygous mutations are related with HHG (8).

The differential diagnosis of $\mathrm{AHC}$ includes $\mathrm{CAH}$, adrenoleukodystrophy, and exceptionally, congenital defects of the hypothalamus and pituitary (13). Careful clinical evaluation and hormonal measurements are essential for the diagnosis. In our patient, the serum levels of $17-\mathrm{OH}$ progesterone and other measured steroids were low, whereas ACTH level was increased, indicating cortisol deficiency not related to 21-hydroxylase or other adrenal enzyme deficiencies. Saltwasting crisis with high renin levels showed aldosterone deficiency. Normal male genital development indicated that testosterone synthesis was normal. Primary adrenal failure that was not associated with adrenal steroid biosynthesis defect suggested failure in adrenal gland development and led to the analysis of DAX1 gene by which the mutation was detected. Baseline and stimulated serum DHEA-S levels of our patient were not as low as expected, findings which might be due to normal production of DHEA by the testes, which can cross-react with DHEA-S (in the analysis) derived from the adrenal. It is also possible that the fetal adrenal zone, the major fetal source of DHEA and DHEA-S, had developed despite DAX1 deficiency.

The mutational analysis of DAX1 is important not only for the provision of correct genetic advice to the families but also for the appropriate management of the patients. A typical example of the unfortunate outcome of such cases is the report of a male patient who had been followed as a case of $\mathrm{CAH}$ until 24 years of age when he was admitted with gonadal failure and was found to have a mutation in the DAX1 gene (28). Although at present only the adrenal gland 
of our patient seems to be affected, his pituitary and gonadal functions will be carefully evaluated at his follow-up visits.

\section{Acknowledgements}

The authors thank Joseph A.Majzoub, M.D. (Chief, Division of Endocrinology, Boston Children's Hospital, Harvard Medical School) for his comments and suggestions for the patient's evaluation and for careful review of this manuscript.

\section{References}

1. Miller WL, Achermann JC, Flück CE. The adrenal cortex and its disorders. In: Sperling MA (ed). Pediatric Endocrinology: Philadelphia PA, Saunders Elsevier, 2008:444-511

2. Laverty CRA, Fortune DW, Beischer NA. Congenital idiopathic adrenal hypoplasia. Obstet Gynecol 1973;41:655-664.

3. Ostermann S, Salvi R, Lang-Muritano M, Voirol MJ, Puttinger R, Gaillard RC, Schoenle E, Pralong FP. Importance of genetic diagnosis of DAX-1 deficiency: example from a large, multigenerational family. Horm Res 2006;65:163-168.

4. Lin L, Gu WX, Ozisik G, To WS, Owen CJ, Jameson JL, Achermann JC. Analysis of DAX1 (NR0B1) and steroidogenic factor-1 (NR5A1) in children and adults with primary adrenal failure: ten years' experience. J Clin Endocrinol Metab 2006;91:3048-3054. Epub 2006 May 9

5. Zanaria E, Muscatelli F, Bardoni B, Strom TM, Guioli S, Guo W, Lalli $\mathrm{E}$, Moser C, Walker AP, McCabe ERB, Meitinger T, Monaco AP, Corsi PS, Camerino G. An unusual member of the nuclear hormone receptor superfamily responsible for X-linked adrenal hypoplasia congenita. Nature 1994;372:635-641.

6. Guo W, Burris TP, McCabe ER. Expression of DAX-1, the gene responsible for X-linked adrenal hypoplasia congenita and hypogonadotropic hypogonadism, in the hypothalamicpituitary-adrenal/gonadal axis. Biochem Mol Med 1995; 56:8-13.

7. Achermann JC, Meeks JJ, Jameson JL. Phenotypic spectrum of mutations in DAX-1 and SF-1. Mol Cell Endocrinol 2001;185:17-25.

8. Merke DP, Tajima T, Baron J, Cutler GB Jr. Hypogonadotropic hypogonadism in a female caused by an X-linked recessive mutation in the DAX1 gene. N Engl J Med 1999;340:1248-1252.

9. Pélissier P, Merlin E, Prieur F, David M, Malpuech G, Forest MG, Morel Y, Nicolino M, Richard O, Stéphan JL. (Adrenal hypoplasia congenita: four new cases in children). Arch Pediatr 2005;12:380384.

10. Uttley WS. Familial congenital adrenal hypoplasia. Arch Dis Child 1968:43:724-730

11. Achermann JC, Silverman BL, Habiby RL, Jameson JL. Presymptomatic diagnosis of $\mathrm{X}$-linked adrenal hypoplasia congenita by analysis of DAX1. J Pediatr 2000;137:878-881.

12. Garagorri JM, Rodríguez G, Lario-Elboj AJ, Olivares JL, LarioMuñoz A, Orden I. RReference levels for 17-hydroxyprogesterone, 11-desoxycortisol, cortisol, testosterone, dehydroepiandrosterone sulfate and androstenedione in infants from birth to six months of age. Eur J Pediatr 2008;167:647-653. Epub 2007 Aug 11

13. Ozer EA, Kaya A, Yildirimer M, Guler O, Can S, Aydinlioglu H. A novel DAX1 gene mutation in a Turkish infant with X-linked adrenal hypoplasia congenita. Eur J Pediatr 2009;168:367-369. Epub 2008 Jul 15

14. Darcan S, Goksen D, Ozen S, Ozkinay F, Durmaz B, Lalli E. Gonadotropin-dependent precocious puberty in a patient with X-linked adrenal hypoplasia congenita caused by a novel DAX-1 mutation. Horm Res Paediatr 2011;75:153-156. Epub 2010 Oct 22

15. Reutens AT, Achermann JC, Ito M, Ito M, Gu WX, Habiby RL, Donohoue PA, Pang S, Hindmarsh PC, Jameson JL. Clinical and functional effects of mutations in the DAX-1 gene in patients with adrenal hypoplasia congenita. J Clin Endocrinol Metab 1999;84:504511.
16. Muscatelli F, Strom TM, Walker AP, Zanaria E, Recan D, Meindl A, Bardoni B, Guioli S, Zehetner G, Rabl W, Schwarz HP, Kaplan JC, Camerino G, Meitinger T, Monaco AP. Mutations in the DAX1 gene give rise to both $X$-linked adrenal hypoplasia congenita and hypogonadotropic hypogonadism. Nature 1994;372:672-676.

17. Takahashi T, Shoji Y, Shoji Y, Haraguchi N, Takahashi I, Takada G. Active hypothalamic-pituitary-gonadal axis in an infant with X-linked adrenal hypoplasia congenita. J Pediatr 1997;130:485-488.

18. Nakae J, Tajima T, Kusuda S, Kohda N, Okabe T, Shinohara N, Kato M, Murashita M, Mukai T, Imanaka K, Fujieda K. Truncation at the $\mathrm{C}$-terminus of the DAX-1 protein impairs its biological actions in patients with X-linked adrenal hypoplasia congenita. J Clin Endocrinol Metab 1996;81:3680-3685.

19. Nakae J, Abe S, Tajima T, Shinohara N, Murashita M, Igarashi Y, Kusuda S, Suzuki J, Fujieda K. Three novel mutations and a de novo deletion mutation of the DAX-1 gene in patients with X-linked adrenal hypoplasia congenita. J Clin Endocrinol Metab 1997;82:3835-3841.

20. Schwartz M, Blichfeldt S, Müller J. X-linked adrenal hypoplasia in a large Greenlandic family. Detection of a missense mutation (N4401) in the DAX-1 gene; implication for genetic counselling and carrier diagnosis. Hum Genet 1997;99:83-87.

21. Peter M, Viemann M, Partsch CJ, Sippell WG. Congenital adrenal hypoplasia: clinical spectrum, experience with hormonal diagnosis, and report on new point mutations of the DAX-1 gene. J Clin Endocrinol Metab 1998;83:2666-2674.

22. Verrijn Stuart AA, Ozisik G, de Vroede MA, Giltay JC, Sinke RJ, Peterson TJ, Harris RM, Weiss J, Jameson JL. An amino-terminal DAX1 (NROB1) missense mutation associated with isolated mineralocorticoid deficiency. J Clin Endocrinol Metab 2007;92:755761. Epub 2006 Dec 12

23. Landau Z, Hanukoglu A, Sack J, Goldstein N, Weintrob N, Eliakim A, Gillis D, Sagi M, Shomrat R, Kosinovsky EB, Anikster Y. Clinical and genetic heterogeneity of congenital adrenal hypoplasia due to NROB1 gene mutations. Clin Endocrinol (Oxf) 2010;72:448-454. Epub 2009 Jun 8

24. Li N, Liu R, Zhang H, Yang J, Sun S, Zhang M, Liu Y, Lu Y, Wang W, Mu Y, Ning G, Li X. Seven novel DAX1 mutations with loss of function identified in Chinese patients with congenital adrenal hypoplasia. J Clin Endocrinol Metab 2010;95:104-111. Epub 2010 Jun 23

25. Calliari $L E$, Longui $C A$, Rocha $M N$, Faria $C D$, Kochi $C$, Melo $M R$, Melo MB, Monte O. A novel mutation in DAX1 gene causing different phenotypes in three siblings with adrenal hypoplasia congenita. Genet Mol Res 2007;6:277-283.

26. Sykiotis GP, Hoang XH, Avbelj M, Hayes FJ, Thambundit A, Dwyer A, Au M, Plummer L, Crowley WF, Jr., Pitteloud N. Congenital idiopathic hypogonadotropic hypogonadism: evidence of defects in the hypothalamus, pituitary, and testes. J Clin Endocrinol Metab 2010; 95:3019-3027. Epub 2010 Apr 9

27. Habiby RL, Boepple P, Nachtigall L, Sluss PM, Crowley WF Jr, Jameson JL. Adrenal hypoplasia congenita with hypogonadotropic hypogonadism: evidence that DAX-1 mutations lead to combined hypothalmic and pituitary defects in gonadotropin production. J Clin Invest 1996; 98:1055-1062.

28. Esden-Tempska Z, Lewczuk A, Tobias ES, Borozdin W, Kohlhase J, Sworczak K. Delayed diagnosis of adrenal hypoplasia congenita in a patient with a new mutation in the NROB1 gene. J Pediatr Endocrinol Metab 2012;25:147-148.

29. Guoying C, Zhiya D, Wei W, Na L, Xiaoying L, Yuan X, Defen W. The analysis of clinical manifestations and genetic mutations in Chinese boys with primary adrenal insufficiency. J Pediatr Endocrinol Metab 2012:25:295-300.

30. Jadhav $U$, Harris RM, Jameson JL. Hypogonadotropic hypogonadism in subjects with DAX1 mutations. Mol Cell Endocrinol 2011;346:65-73. Epub 2011 Jun 13

31. Hay ID, Smail PJ, Forsyth CC. Familial cytomegalic adrenocortical hypoplasia: an X-linked syndrome of pubertal failure. Arch Dis Child $1981 ; 56: 715-721$ 